\title{
The formation of quartz aggregates in ultra-acid volcanics from eruptive breccias of the Pechenga structure (Kola Peninsula)
}

\section{Introduction}

In the ore field of the Zhdanovsky $\mathrm{Cu}-\mathrm{Ni}$ deposit of Pechenga structure, on the eastern flank of the Productive suite, bodies of eruptive breccias of a bimodal kagusite-picrobasalt composition are observed, which are observed in the form of split straight-line accordant dikes confined to the contact of the rocks of Productive suite and overlying rocks of the Matert suite. The author was in some difficulty when trying to identify these exotic rocks and considered the most correct to give them the name "Kagusites", which is S.I. Tomkeev provides for non-feldspar ultra-acid magnetite rhyolites of the African volcano Kagusi. ${ }^{1}$

Dikes of this group can be traced for hundreds of meters along the strike and fall of the host rocks and reach a thickness of 25-30 meters. The dikes cut ferro-dolerite sill-like bodies that are common in the section of the Productive suite, and in turn are cut by the intrusions of the ore-bearing gabbro-wehrlite association (Figure 1). Macroscopically, these are dense massive fragmentary lava with a breccia texture, in which randomly distributed fragmentary material is immersed in a matrix represented by vitroclastic microlava-brereccia having a composition of subalkaline picrobasalt enriched in $\mathrm{Ti}, \mathrm{Mg}$ and $\mathrm{Fe}$ (Table 1) and constituting $20-50 \%$ of the rock volume (Figure 1). The size of the debris varies from psammite particles to lumps having more than $400 \mathrm{~mm}$ in diameter; form is angular, rounded, lamellar. More than $90 \%$ of the debris is represented by iron-rich ultra-siliceous lavas (kagusites) - dense glassy rocks of black or light
Volume 3 Issue I - 2019

\author{
Petr Skuf'in \\ Geological Institute of the Kola Science Center of the RAS, \\ Russia
}

\author{
Correspondence: Petr Skuf'in, Geological Institute of the Kola \\ Science Center of the RAS, Apatity, Russia, \\ Email skuf@geoksc.apatity.ru
}

Received: January 23, 2019 | Published: January 30, 2019

gray color, with a conchoidal fracture characteristic of siliceous rocks. Large fragments of cagusite, "floating" in the vitroclastic matrix of eruptive breccia, sometimes have a drop-shaped and spindle-shaped, often twisted shape - a sign of synvolcanic plastic deformations of lava fragments; often, a crust of quenching with a thickness of 0.5$1 \mathrm{~cm}$, composed of glass material and turbid with finely dispersed magnetite, is fixed in fragments. The structure of kagusite is microporphyritic or crypto-porphyritic; the number of porphyritic crystals is from 3 to $8 \%$ of the rock volume, the composition is quartz, sometimes dipyramidal quartz, which forms pseudomorphs in the crystals of high-temperature cristobalite; rarely albite and anorthite; the main enclosing material is an isotropic aggregate of the smallest quartz grains, sometimes of honeycomb shape. Among porphyritic phenocrysts, volume-decomposing feldspar and quartz crystalloclasts typical of modern eruptive breccias are often observed. Among the kagusites, two coexisting varieties of black and light gray can be distinguished (Figure 2).

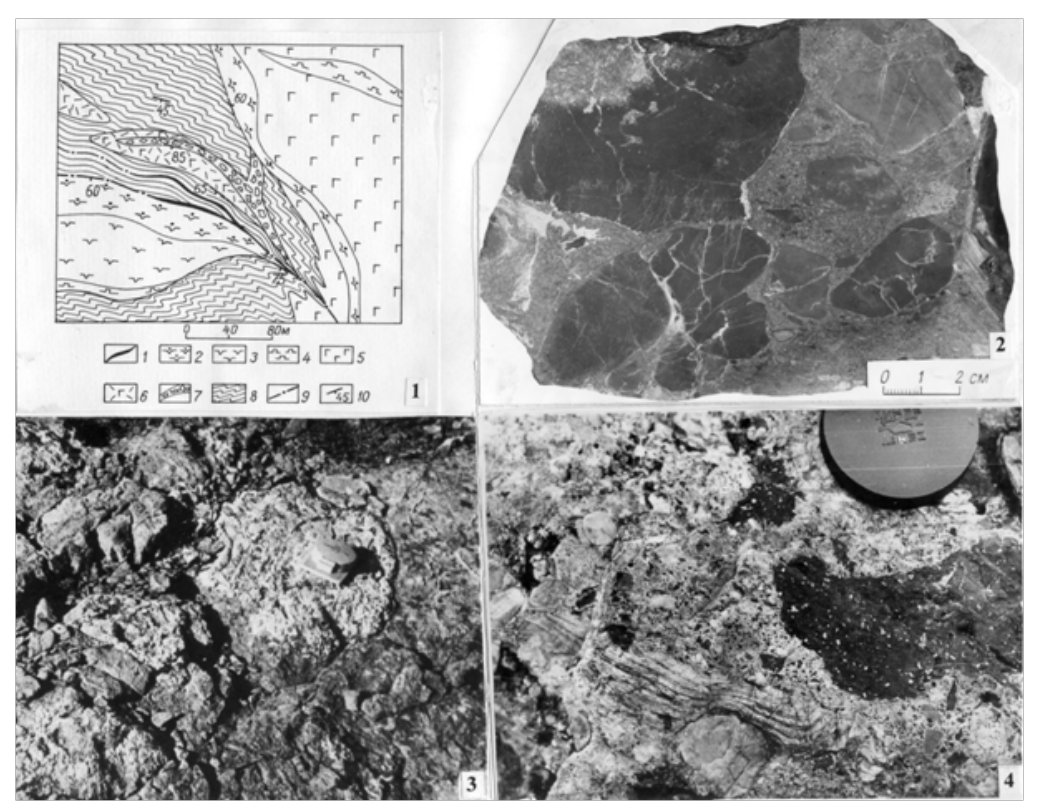

Figure I (I) Schematic geological map of a section of the Ore field to the west of the Zhdanovsky deposit. Legend: I, Cu-Ni ore; 2,3, metaperidotites; 4, pyroxenites; 5 , gabbros; 6 , ferrodolerites; 7 , rocks of the eruptive breccia of kagusite-basalt composition; 8 , metasediments; 9 , faults; 10 , occurrence of rocks.

(2) Eruptive breccia of kagusite-basalt composition (sample photo). Fragments of a kagusite are immersed in basalt vitroclastite.

(3) Rounded kagusite isolations in the eruptive lava-breccia of basalt composition (outcrop photo).

(4) Coarse fragmentary sintered tuff (outcrop photo). Porphyritic black fragments - eucrites, rounded and ribbon-like fragments with a fluid texture - kagusites. 
Table I The chemical composition of bimodal kagusite-containing associations of eruptive breccias of areas of Zhdanovsky deposit and Lake Sari-Yarvi (wt.\%, ppm)

\begin{tabular}{|c|c|c|c|c|c|c|}
\hline Components & 1 & 2 & 3 & 4 & 5 & 6 \\
\hline $\mathrm{SiO}_{2}$ & 49.59 & 41.63 & 83.62 & 94.73 & 42.49 & 86.1 \\
\hline $\mathrm{TiO}_{2}$ & 1.65 & 1.56 & 0.27 & 0 & 1.78 & 0.51 \\
\hline $\mathrm{Al}_{2} \mathrm{O}_{3}$ & 12.75 & 11.83 & 2.73 & 0.34 & 12.3 & 3.22 \\
\hline $\mathrm{Fe}_{2} \mathrm{O}_{3}$ & 7.98 & 4.03 & 1.01 & 0.53 & 5.45 & 1.18 \\
\hline $\mathrm{FeO}$ & 4.06 & 6.71 & 1.29 & 1.78 & 12.82 & 3.75 \\
\hline $\mathrm{MnO}$ & 0.17 & 0.19 & 0.04 & 0.01 & 0.2 & 0.06 \\
\hline $\mathrm{MgO}$ & 10.23 & 7.2 & 1.36 & 0.18 & 5.96 & 1.77 \\
\hline $\mathrm{CaO}$ & 4.07 & 10.85 & 3.41 & 0.8 & 11.77 & 0.98 \\
\hline $\mathrm{Na}_{2} \mathrm{O}$ & 4.2 & 3.54 & 1.5 & 0.1 & 0.38 & 0.09 \\
\hline $\mathrm{K}_{2} \mathrm{O}$ & 0.24 & 1.35 & 0.14 & 0.03 & 0.16 & 0.01 \\
\hline $\mathrm{H}_{2} \mathrm{O}^{-}$ & 0.12 & 0.1 & 0 & 0.06 & 0.33 & 0.25 \\
\hline $\mathrm{H}_{2} \mathrm{O}^{+}$ & 3.2 & 3.69 & 1.66 & 0.35 & 5.05 & 2.05 \\
\hline $\mathrm{P}_{2} \mathrm{O}_{5}$ & 0.13 & 0.12 & 0.19 & 0 & 0.12 & 0 \\
\hline $\mathrm{CO}_{2}$ & 0.12 & 6.38 & 2.13 & 0.59 & 0.65 & 0.26 \\
\hline Stot & 1.26 & 1.19 & 0.02 & 0.4 & 0.55 & 0 \\
\hline$\Sigma$ & 99.77 & 100.37 & 99.37 & 99.9 & 100.01 & 100.23 \\
\hline $\mathrm{Rb}$ & 10 & n.det. & 5 & n.det. & 4 & 0 \\
\hline $\mathrm{Sr}$ & 118 & n.det. & 71 & n.det. & 90 & n.det. \\
\hline $\mathrm{Ba}$ & 140 & н.оп. & 40 & n.det. & 80 & n.det. \\
\hline $\mathrm{Ni}$ & n.det. & 200 & n.det. & 100 & 200 & 100 \\
\hline $\mathrm{Co}$ & n.det. & 50 & n.det. & 0 & 90 & 0 \\
\hline $\mathrm{Cr}$ & n.det. & 460 & n.det. & 190 & 500 & 400 \\
\hline $\mathrm{Cu}$ & n.det. & 160 & n.det. & 40 & n.det. & 25 \\
\hline $\mathrm{Zr}$ & 115 & n.det. & 25 & n.det. & n.det. & n.det. \\
\hline
\end{tabular}

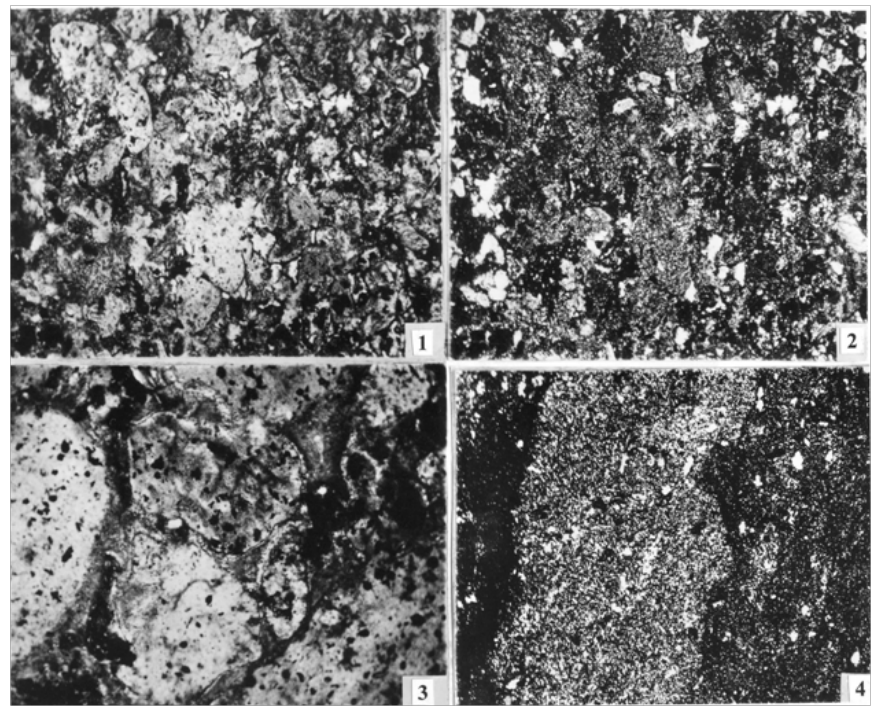

Figure 2 Rocks of eruptive breccia of the kagusit-basaltic composition from the section of the Productive suite (thin sections photo).

(I) \& (2), A form of likvate kidney-shaped kagusitic isolations (light gray) in basaltic vitro-clastite; $\times$ I5; I - without analyzer; 2 - with the analyzer;

(3) The form of likvate kagusitic isolations, a fragment of the previous section; $\times 60$, without analyzer;

(4) Strip-like isolation of alkali-free kagusite (gray) in a low-alkaline kagusite (dark gray); $\times 35$, with the analyzer.

From Table 1, it can be seen that the kagusites of the described bimodal eruptive breccias are represented by two types of rocks low-alkaline kagusites (black varieties) and alkali-free kagusites (leucocratic varieties of light gray). The $\mathrm{SiO}_{2}$ content in the low alkaline kagusite is $83.62 \%$, and the total $\mathrm{Fe}$ is $2.5 \%$; $\mathrm{Na}_{2} \mathrm{O}+\mathrm{K}_{2} \mathrm{O}=$ $1.64 \%$, with a predominance of $\mathrm{Na}_{2} \mathrm{O}$. The content of $\mathrm{SiO}_{2}$ in alkali free kagusite is $94.73 \%$, and total $\mathrm{Fe}$ is $2.31 \%$; $\mathrm{Na}_{2} \mathrm{O}+\mathrm{K}_{2} \mathrm{O}=0.13 \%$, with a predominance of $\mathrm{Na}_{2} \mathrm{O}$. In all cases, the matrix of eruptive breccia is sub-alkaline iron-rich picrobasalts. A peculiar body of ferrobasaltic lavobreccia with fragments of alkali-free kagusites was established in the area of Lake Sari-Yarvi, north of the Kola Superdeep Well. ${ }^{3}$ Having a size of up to $450 \mathrm{~m}$ in diameter and a complex rodshaped form, this body pierces a powerful sill of gabbro-dolerites at the contact of rocks of the Productive suite and the suite of Matert. In addition to the acute-angled fragments of basaltic ferrodolerites, this body is crowded with rounded kagusite fragments measuring $0.2-0.5$ $\mathrm{m}$ in diameter (Figure 1).

The content of $\mathrm{SiO}_{2}$ in the kagusite from the area of Lake SariYarvi is $86.1 \%$, and total $\mathrm{Fe}$ is $4.9 \%$; $\mathrm{Na}_{2} \mathrm{O}+\mathrm{K}_{2} \mathrm{O}=0.1 \%$. A distinctive feature of the kagusitic bimodal association areas of Lake Sari-Yarvi and Zhdanovsky deposit is enrichment of some siderophilic and chalcophilic elements, in particular, $\mathrm{Cr}, \mathrm{Cu}$ and Ni. Kagusites have a cryptofelsitic structure, enriched with finely divided magnetite and permeated with a network of quartz veins. Lavobreccia matrix is represented by subalkaline picrobasalt. The chemical composition of kagusite, as well as low-alkaline ferrobasalt is given in Table 1.

At present, the significant role of the Kagusite-basalt splitting in the formation of sulfide-noble metal mineralization of the Pechenga structure $^{3}$ is proved. However, this problem must be considered much broader. The alkaline (alkali-metal) character of the Kagusites acquires with a decrease in their composition $\mathrm{Al}_{2} \mathrm{O}_{3}$, with a lack of which, instead of the formation of feldspar and mica, alkaline 
hydroxides of $\mathrm{K}(\mathrm{OH})$ and others, or their corresponding sulfide and halide complexes, occur. As a result of their formation, the solubility of ore, including noble, metals in Kagusite melts with a sufficiently high alkali-metal composition may significantly exceed their solubility in silicate melts, and even more so in transmagmatic fluids (hydrothermal solutions), which are distinguished by low solubility of ore metals in them. Kagusite melts, practically free of aluminum, are the most favorable medium for the efficient extraction of gold from silicate melts. Moreover, this extraction plays a major role not only in the formation of gold quartz veins, but in combination with the agpaitic character of the Kagusites, this factor can contribute to the formation of large and even gigantic ore deposits, such as Witwatersrand in Africa. In the geological literature, the idea of the Witwatersrand ores is common as alluvial conglomerates containing sedimentary quartz pebbles. This contradicts modern ideas that these are pseudo-conglomerates. ${ }^{3}$ Quartz emissions in them have bizarre forms and are connected to each other by bridges, reflecting their formation as a result of the development of liquid immiscibility in initially homogeneous fluid melts. Platinum minerals and chromite in these ores reflect the connection between the mineralization of the deposit and the deep development of basite-hyperbasite magmatism. Probably, gold-bearing fluid melts were periodically thrown out by explosions, like tagamite or zjuvite melts of explosive pseudoastroblems, and formed covers (gold-bearing reefs) throughout the long formation of the structure, which created its unique gold-bearing capacity. The grandeur of these explosions is recorded by the presence of small diamond grains that make up U-Au ores.

\section{Acknowledgment}

Research conducted with the support of grant No. 16-05-00026.

\section{Conflicts of interest}

The author declares that there is no conflict of interest.

\section{References}

1. Tomkeev SI. Petrological English-Russian explanatory dictionary. Volume 1. Mosk Mir. 1986;285.

2. Marakushev AA, Bezmen NI. Variolites and their petrogenetic significance. Vestn Mosk Univ Ser Geol. 1987;5:62-77.

3. Skuf'in PK. Kagusit-basaltic splitting in igneous rocks of the Pechenga structure and the influence of this process on the formation of sulfidenoble metal mineralization. Bull Mosk Ob-va isp Nature section Geol. 2010;85(3):52-68. 